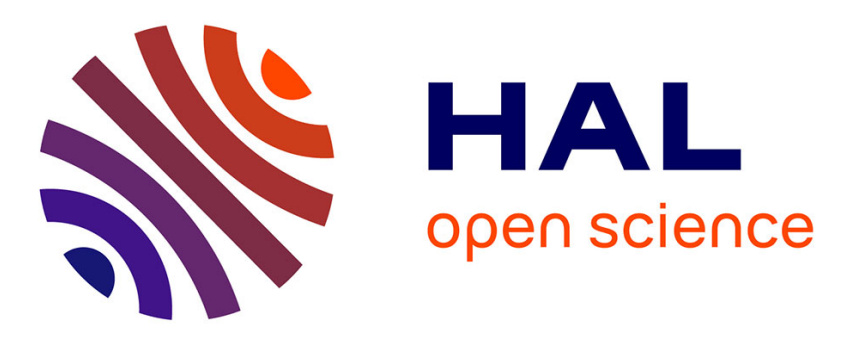

\title{
Identification of evolutionary significant units in the Spanish wild goat, Capra pyrenaica (Mammalia, Artiodactyla)
}

Valerie Manceau, Jean-Paul Crampe, Pierre Boursot, Pierre Taberlet

\section{To cite this version:}

Valerie Manceau, Jean-Paul Crampe, Pierre Boursot, Pierre Taberlet. Identification of evolutionary significant units in the Spanish wild goat, Capra pyrenaica (Mammalia, Artiodactyla). Animal Conservation, 1999, 2 (1), pp.33-39. 10.1111/j.1469-1795.1999.tb00046.x . halsde-00280575

\section{HAL Id: halsde-00280575 https://hal.science/halsde-00280575}

Submitted on 19 Jan 2021

HAL is a multi-disciplinary open access archive for the deposit and dissemination of scientific research documents, whether they are published or not. The documents may come from teaching and research institutions in France or abroad, or from public or private research centers.
L'archive ouverte pluridisciplinaire HAL, est destinée au dépôt et à la diffusion de documents scientifiques de niveau recherche, publiés ou non, émanant des établissements d'enseignement et de recherche français ou étrangers, des laboratoires publics ou privés. 
Identification of evolutionary significant units in the Spanish wild goat, Capra pyrenaica (Mammalia, Artiodactyla)

Valérie Manceau ${ }^{1}$, Jean-Paul Crampe ${ }^{2},{\text { Pierre } \text { Boursot }^{3} \text {, and Pierre Taberlet }}^{1}$

${ }^{1}$ Laboratoire de Biologie des Populations d'Altitude, CNRS UMR 5553, Université Joseph Fourier, BP 53, F-38041 Grenoble Cedex 9, France

2Parc National des Pyrénées, 59, route de Pau, 65000 Tarbes, France

${ }^{3}$ Laboratoire Génome et Populations, CNRS UPR 9060, Université de Montpellier II, Place Eugène Bataillon, C.C.63, F-34095 Montpellier Cedex 5, France

\footnotetext{
Abstract

The Pyrenean population of Spanish wild goat (Capra pyrenaica pyrenaica) is nearly extinct. To find the most appropriate source of individuals for supplementing the Pyrenean population, we identified Evolutionary Significant Units (ESUs) among populations of the Capra pyrenaica species. We have examined sequence variability of portions of the mitochondrial DNA (mtDNA) control region and cytochrome $b$ (cyt b) gene. Samples were from seven populations of Spanish wild goat distributed over the species' geographic range. The level of divergence between the Pyrenean and other Spanish haplotypes is almost as high as the divergence between the Alpine $(C$. ibex ibex) and the Spanish wild goats. In addition, the Pyrenean goat is morphologically distinct from other Spanish wild goats. Therefore the Pyrenean population should be considered as an ESU. For the reinforcement, we suggest either using individuals from the most polymorphic Spanish population, or mixing individuals from diverse Spanish origins, since all the other Spanish populations are equally genetically distant from the Pyrenean population.
}

\section{INTRODUCTION}

In Western Europe, wild goats are found in the Alps and in the Spanish Mountains. Most authors (Schaller, 1977; Corbet, 1978; Nowak, 1991) recognize two different species according to morphological criteria. The Spanish wild goat (Capra pyrenaica) is characterized by its curved horns, whereas the Alpine wild goat (Capra ibex ibex) has scimitar-shaped horns. Because of excessive hunting, the populations of these species were sharply reduced. In the Alps, the 
population has declined since the 15 th century. When they were first protected, in 1821 , only about 100 individuals remained in the Grand Paradiso Mountain (Grodinsky \& Stüwe, 1987). In the Spanish Peninsula, the protection of about 10 small remnant populations was initiated between 1900 and 1960. At this time, several hundred individuals still survived in the Sierra-Nevada population and only between 5 and 30 individuals in the other populations (Crampe, 1991; see Fig. 1). In the Pyrenees, the population has been greatly reduced since the beginning of the 20th century and the last remaining individuals, living in the Ordesa valley on the Spanish Pyrenean side, were protected in 1918.

In most of these protected areas, populations have substantially recovered in recent years. But in the Pyrenees, despite the strict protection, the population has never increased and is now composed of only two females. In order to restore wild goats to this area a European conservation project has been considered for several years. Two alternative conservation strategies have been under consideration: either hybridize the two remaining Pyrenean females with males from other populations followed by several back-crosses or, simply release individuals from other Spanish populations into the Pyrenees. The first strategy is based on a reproductive program in captivity involving in vitro fertilization of the Pyrenean ova and subsequent embryo transplants into domestic goats to improve the reproductive rate.

The taxonomy of the Spanish wild goat, accepted by the International Union for the Conservation of Nature and Natural Resources (IUCN; Shackleton, 1997), recognizes four subspecies: C. pyrenaica lusitanica, now extinct and formally located in northern Portugal and southern Galicia; C. p. pyrenaica, in the Pyrenees; C. p. victoriae, in the Sierra de GredosBatuecas and C. p. hispanica, in the South and East of the peninsula (see 



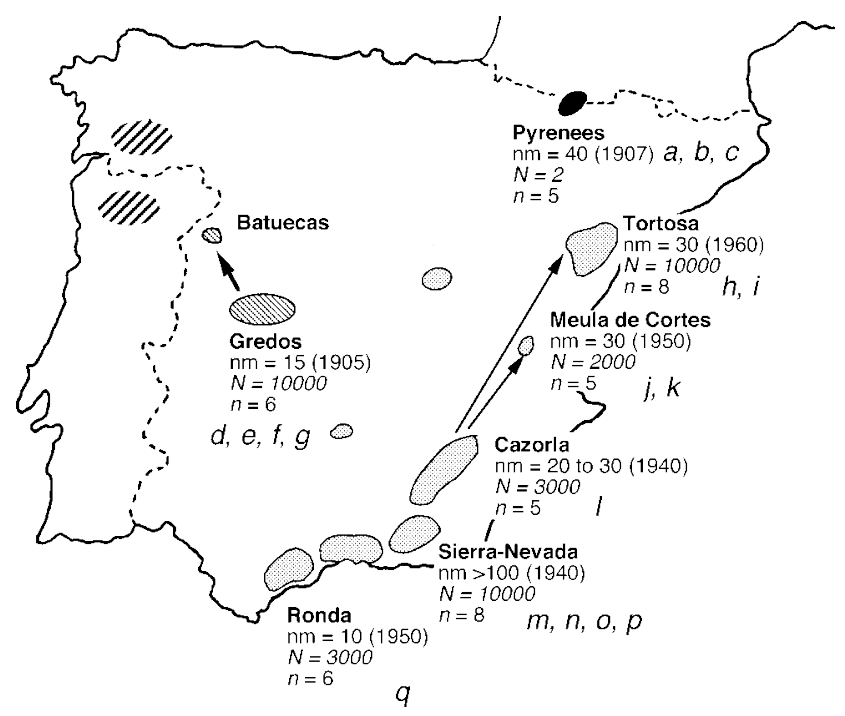

Fig. 1. Geographic distribution of populations studied. The taxonomically recognized subspecies of Capra pyrenaica (Cabrera, 1911) are noted. nm, indicates the minimum historic population size; $N$, the present population size. Arrows show translocation of individuals from Gredos to Batuecas (reintroduction) and from Cazorla to Muela de Cortes and Tortosa (reinforcement). $n$ is the number of samples analysed per population to estimate the withinpopulation polymorphism. The 17 individuals ( $a$ to $q$ ) studied to make the phylogenetic inference are also localized on the map.

- , Capra pyrenaica pyretica;

Capra pyrenatca victoriae ; Capra pyrenaica hispanica ; $\mathbb{Z}$, Capra pyrenaica lusitanica (extinct).

Fig. 1). However, this taxonomy is questionable because it is based on only two morphological criteria: coat colour and horn morphology (Cabrera, 1911). Moreover, these characters are variable within populations (Couturier, 1962; Clouet, 1979). They could also be influenced by sexual or environmental selection (Clouet, 1979) and could be poor indicators of the long-term history of populations. To test the morphologically recognized taxonomy of $C$. pyrenaica with other independent criteria and to retrace the evolutionary history of this species, we studied mitochondrial DNA (mt DNA) sequence polymorphism. We sequenced mtDNA fragments from the control region and the cytochrome $b$ (cyt b) gene from populations throughout the geographic range of the species. We tested for concordance between our mtDNA data and existing morphological data in order to define Evolutionary Significant Units (ESUs) as populations or groups of populations that have been historically isolated and represent an important evolutionary 
legacy (Ryder, 1986; Avise \& Ball, 1990; Waples, 1991; Moritz, 1994). Indeed, defining ESUs is of major importance in guiding the conservation strategies of C. pyrenaica, especially for the preservation of the species in the Pyrenees.

\section{MATERIALS AND METHODS}

\section{Samples and DNA extraction}

Forty three Spanish wild goats from seven populations were sampled. Fig. 1 shows the number of individuals analysed per population, the actual population sizes, as well as the minimum population sizes during bottlenecks and previous translocations. Four Pyrenean samples were obtained from museum bones dating from 1867 to 1980. All other samples were collected in the field. In protected areas, blood was collected from individuals by using anaesthesia and a dart gun. In hunting areas, organs (liver, muscle, kidney or skin) were collected from animals killed by hunters. Blood was preserved in a Tris-EDTA (ethylene diamine tetra acetate) buffer (Hoelzel, 1992) and organs in $70 \%(w / v)$ ethanol.

DNA was extracted from organ or blood samples using proteinase $\mathrm{K}$ digestion followed by extraction with phenol/chloroform and precipitation with ethanol. DNA was extracted from bones using a silica-based method (Boom et al., 1990). The bones were first carefully cleaned using sterilized tools and compressed air and then a small piece (about $20 \mathrm{mg}$ ) was crushed in a mortar with liquid nitrogen. DNA was extracted as described by Taberlet \& Fumagalli (1996).

\section{Amplification of the mtDNA}

Two primer sets were used to amplify the two hypervariable left (zone I) and right (zone II) domains of the control region (see Fig. 2 for location and sequence of the primers). The cyt $b$ gene was amplified using the universal primers L14841 and H15915 (Irwin, Kocher \& Wilson, 1991).

With highly concentrated DNA, extracted from blood or organs, double-stranded amplifications were performed in a $25 \mu 1$ volume containing $200 \mathrm{mM}\left(\mathrm{NH}_{4}\right)_{2} \quad \mathrm{SO}_{4}, 750 \mathrm{mM}$ Tris- $\mathrm{HCl}(\mathrm{pH} 9), 1.5$ $\mathrm{mM} \mathrm{MgCl} 2,1 \mu \mathrm{M}$

of each primer, $50 \mu \mathrm{M}$ of each dNTP, 0.1 units of Taq polymerase (Goldstar, Eurogentec). Thirty cycles (denaturation: $93^{\circ} \mathrm{C}, 45 \mathrm{~s}$; annealing: $55^{\circ} \mathrm{C}, 45 \mathrm{~s}$; polymerization: $72^{\circ} \mathrm{C}, 120 \mathrm{~s}$ ) were performed.

With diluted DNA, extracted from bones, a two-step polymerase chain reaction (PCR) (Ruano, Fenton \& Kidd, 1989) was performed. Bovine serum albumin (5 ng) was added to the above 
reaction buffer. In the first step, diluted primers $(0.01 \mu \mathrm{M})$ were used in order to reduce the formation of primer-dimer artefacts, and in the second step, a reaction buffer with concentrated primers $(1 \mu \mathrm{M})$ was added. Twenty-five cycles were performed with diluted primers and 45 additional cycles were carried out after the addition of buffer with concentrated primers.

\section{Direct sequencing of PCR products}

The control region was sequenced using the T7 Pharmacia manual sequencing kit. Doublestranded DNA was purified on an agarose gel and used as a tem- 


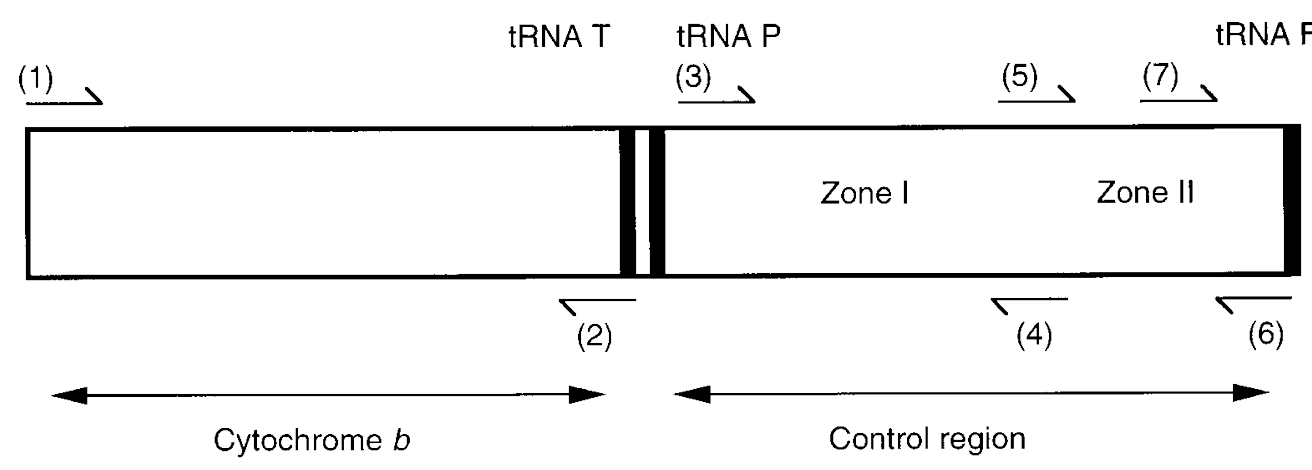

Fig. 2. Localization of the primer sets used to amplify and sequence the control region and the cytochrome $b$ gene. (1) and (2) are universal primers as described by Irwin et al. (1991). The sequence of primers (4) and (5) were deduced from the sequence alignment given by Southern, Southern \& Dizon (1988). (3) and (7) were defined by comparison of homologous sequences of Capra hircus, C. ibex ibex and C. pyrenaica. (6) was defined from the alignment of Bovidae sequences found in nucleotide databases.
(1)
: L14841
(5'-TCAAACATCTCATCATGATGAAA -3')
(2) : H15915
(5'-TCATCTCCGGTTTACAAGAC-3')
(3)
: L15762
(5'-GCCTCACTATCAGCACCCAA-3')
(4) : H16265
(5'-CCTGAAGTAAGAACCAGATG-3')
(5) : L16284
(5'-CATCTGGTTCTTACTTCAGG-3')
(6)
: H385(5'-TAGGCATTTTCAGTGCCTTG-3')
(7)

\section{: L156(5'-CATAATGGTAGGCATGGGCA-3')}

The codes of the primers (3) to (7) identify the primer 3'-end according to the Bos sequence (Anderson et al., 1982).

plate for asymmetric amplification. Single stranded DNA was then purified by filtration and sequenced using the method described by Sanger, Nicklen \& Coulson (1977). Zone I of the control region was sequenced with the use of H16265 as sequencing primer and zone II, with the use of L16284 and L156 (Fig. 2).

The cyt $b$ region was sequenced using an ABI PRISM ${ }^{T M}$ DNA sequencer (Perkin Elmer) with the L14841 and H15915 primers (Fig. 2). PCR products were purified on QiaQuick columns (Qiagen), and sequencing was performed using the ABI PRISM ${ }^{\mathrm{TM}}$ Dye Terminator Cycle 
Sequencing Ready Reaction Kit. Sequencing reactions underwent 25 cycles of $30 \mathrm{~s}$ at $96^{\circ} \mathrm{C}, 30 \mathrm{~s}$ at $50^{\circ} \mathrm{C}$ and $4 \mathrm{~min}$ at $60^{\circ} \mathrm{C}$ on a $\mathrm{PE} 9600$ thermocycler.

\section{Data analysis}

Partial sequences (273 base-pairs (bp)) within the control region, at the 3' end of zone I, were first analysed for the 43 Spanish wild goats from the seven populations. This allowed us to estimate the within-population variability of this region. Then, for phylogeographic inferences, sequences of zones I and II of the control region (273 bp of zone I and $260 \mathrm{bp}$ of zone II) were obtained from 17 Spanish wild goats noted $a$ to $q$ in Fig.1. We sequenced the control regions of two individuals of Alpine wild goat and used them as outgroups. Phylogenetic relationships were inferred either by a maximum parsimony analysis (MP tree) using the PAUP program (version 3.1.1, Swofford, 1993: branch and bound research) or by a neighbour-joining analysis (NJ tree: Saitou \& Nei, 1987) using the MEGA program (version 1.01, Kumar, Tamura \& Nei, 1993). Distances were corrected for multiple substitutions per site using the Jukes \& Cantor (1969) model. Robustness of the MP and NJ trees was assessed by 100 bootstrap replicates (Felsenstein, 1985).

To estimate the time of divergence between haplotypes, we analysed cyt $b$ sequences. The divergence between Capra and Ovis was used to calibrate the rate of evolution of these sequences. Two independent sources of molecular data (enzymatic data: Hartl et al., 1990; Randi et al., 1991, and mitochondrial DNA data: Upholt \& Dawid, 1977) as well as paleontological records (see Hartl et al., 1990) converge to estimate an average divergence time between Capra and Ovis of around 5-7 million years (Myr). We analysed cyt b gene sequences (987 bp) because this region evolves more slowly than the control region so that homoplasic events are less likely to have occurred since the divergence of the two genera. We compared sequences from one Alpine wild goat, 16 individuals from the seven Spanish populations and Ovis aries (EMBL n $\left.{ }^{0} 56284\right)$. We tested the molecular clock hypothesis with the likelihood ratio test (see Phylip Package Guidelines, version 3.57c: Felsenstein, 1995). Equal rates of mutations along branches of the maximum likelihood (ML) tree were tested by comparing the likelihood of the two ML trees with (MLK algorithm) or without (ML algorithm) assuming a molecular clock. This hypothesis is accepted if the MLK and ML trees have the same topology and if the likelihood is not significantly decreased in the MLK tree. As described by Hillis, Mable \& Moritz (1996, p. 532), we defined the 95\% confidence interval of distance calculated between haplotypes. The lower value of the distance interval between Ovis and Capra divided by the highest divergence time ( $7 \mathrm{Myr}$ ) 
between these two genera gave the smallest evolution rate and the upper distance divided by the smallest time (5 Myr) gave the highest evolution rate. Then, to estimate the date of divergence between haplotypes, we divided the lower value of the $95 \%$ confidence interval of the distance calculated between these haplotypes by the highest mutation rate and the upper value of the distance interval by the smallest mutation rate.

\section{RESULTS}

Out of the $273 \mathrm{bp}$ sequenced at the 3' end of zone I for the 43 Spanish wild goats analysed, 45 sites were variable. We found 19 haplotypes, one from Ronda and one from Cazorla, two from Muela de Cortes, three from Tortosa, four from each of the three remaining populations (GredosBatuecas, Pyrenees and Sierra-Nevada). The mean pairwise sequence divergence within the populations of Ronda, Cazorla, Tortosa, Gredos-Batuecas, Muela de Cortes and Sierra Nevada were respectively $0.0,0.0,0.48,0.88,1.46$ and $1.74 \%$. The mean value is $1 \%$, five times lower than the mean divergence between populations.

We sequenced $260 \mathrm{bp}$ of zone II for 17 individuals ( $a$ to $q$ on Fig. 1) consisting of the 17 most distinct haplotypes of the 19 we found. The mean pairwise genetic distance between the three haplotypes $a, b$ and $c$ from the Pyrenean population and haplotypes from other Spanish populations was 5.3\%, similar to the mean distance between Alpine and Spanish wild goat haplotypes (5.7\%: see Table 1). The mean pairwise divergence between haplotypes from the peninsula was only $2.9 \%$. Of the $533 \mathrm{bp}$ (273 bp of zone I and $260 \mathrm{bp}$ of zone II), 66 were variable and 54 characters were phylogenetically informative. Almost all mutations were transitions. Six equally parsimonious trees (Consistency Index $=0.6$ ) were found, requiring 104 mutational steps. Fig. 3 shows the consensus tree of the parsimony analysis after 100 bootstrap replicates. Groups that were supported by high bootstrap values in the parsimony analysis were also robust in the distance-based analysis (NJ tree, not shown). The two populations from each of SierraNevada and Muela de Cortes were not monophyletic. In the population of Muela de Cortes, haplotype $k$ was closest to haplotype $l$ of Cazorla. We defined three groups (Fig. 3) supported by high bootstrap values: the first one grouping the three Pyrenean haplotypes, the second one the haplotypes $d, e, f$, $g, h, i$ and $j$ from the northern populations of the peninsula (Gredos-Batuecas, Tortosa, Muela de Cortes) and the third one, the haplotypes $l, m, n, o, p$ and $q$ from the southern populations of the peninsula (Ronda, Sierra-Nevada and Cazorla) plus the haplotype $k$. These groups were not all congruent with those defined according to morphological taxonomy (Cabrera, 1911; see Fig. 1).

We sequenced the cyt $b$ gene from the same individuals as above except that only two 
individuals from the Pyrenean population were successfully sequenced (accession numbers: AJ010047 to AJ010056). The Pyrenean haplotype was greatly divergent from the six other Spanish wild goat haplotypes. Mean pairwise sequence divergence between the Pyrenean and the other Spanish haplotypes is $1.6 \%$, almost identical to that between the Alpine and the Spanish wild goat haplo types (1.8\%). The mean pairwise sequence divergence between haplotypes from the peninsula was much lower $(0.1 \%)$.

We dated the divergence of the Alpine, the Pyrenean and the most common haplotype from the peninsula using Ovis aries as an outgroup. The two trees either assuming the molecular clock (MLK) hypothesis, or not assuming it (ML), had the same topology and the likelihood values of these two trees were not statistically different. The molecular clock hypothesis is thus not rejected. We estimated the divergence rate of the cyt $b$ gene to be between 1.2 and $2.9 \%$ per Myr. The divergence of the Alpine from the Spanish haplotypes and the divergence of the Pyrenean from the other Spanish haplotypes were both estimated between 0.5 and $2.5 \mathrm{Myr}$.

\section{DISCUSSION}

\section{Phylogeographic pattern and status of the Pyrenean population}

Although calculated with small sample sizes ( $n=5$ to 8$)$, the within-population polymorphism is consistent with the recent population history: the Muela de Cortes population that has been reinforced has a haplotype $(k)$ related to individuals from the donor population of Cazorla; the Sierra Nevada population, that has experienced the least drastic bottleneck (Fig. 1), is the most 
Table 1. Mean pairwise genetic distance between haplotypes

\begin{tabular}{|c|c|c|c|c|c|c|}
\hline$a, b, c)$ & $\begin{array}{l}\text { Alpine ibex } \\
\qquad(n=2)\end{array}$ & $\begin{array}{l}\text { Pyrenees } \\
(n=3 ;\end{array}$ & $\begin{array}{l}\text { Gredos } \\
(n=4 ; \\
d, e, f, g) \\
\end{array}$ & $\begin{array}{c}\text { Tortosa } \\
(n=2 ; \\
h, i \\
\end{array}$ & $\begin{array}{l}\text { Muela de } \\
\text { Cortes } \\
(n=2 ; j, k\end{array}$ & $\begin{array}{r}\text { Cazo } \\
\text { rla } \\
(n=1 ; \\
1) \\
\end{array}$ \\
\hline Alpine ibex & $*$ & 0.06 & 0.058 & 0.058 & 0.06 & $4^{0.05}$ \\
\hline Pyrenees & & $*$ & 0.059 & 0.054 & 0.053 & $8^{0.04}$ \\
\hline Gredos & & & $*$ & 0.028 & 0.024 & $5^{0.03}$ \\
\hline Tortosa & & & & $*$ & 0.033 & $8^{0.03}$ \\
\hline Muela de Cortes & & & & & * & 0.02 \\
\hline Cazorla & & & & & & $*$ \\
\hline
\end{tabular}

Sierra Nevada

Ronda

Numbers in italic represent the mean distance between Alpine and Spanish haplotypes. For each population, the number of haplotypes studied and their labels are noted between brackets. 


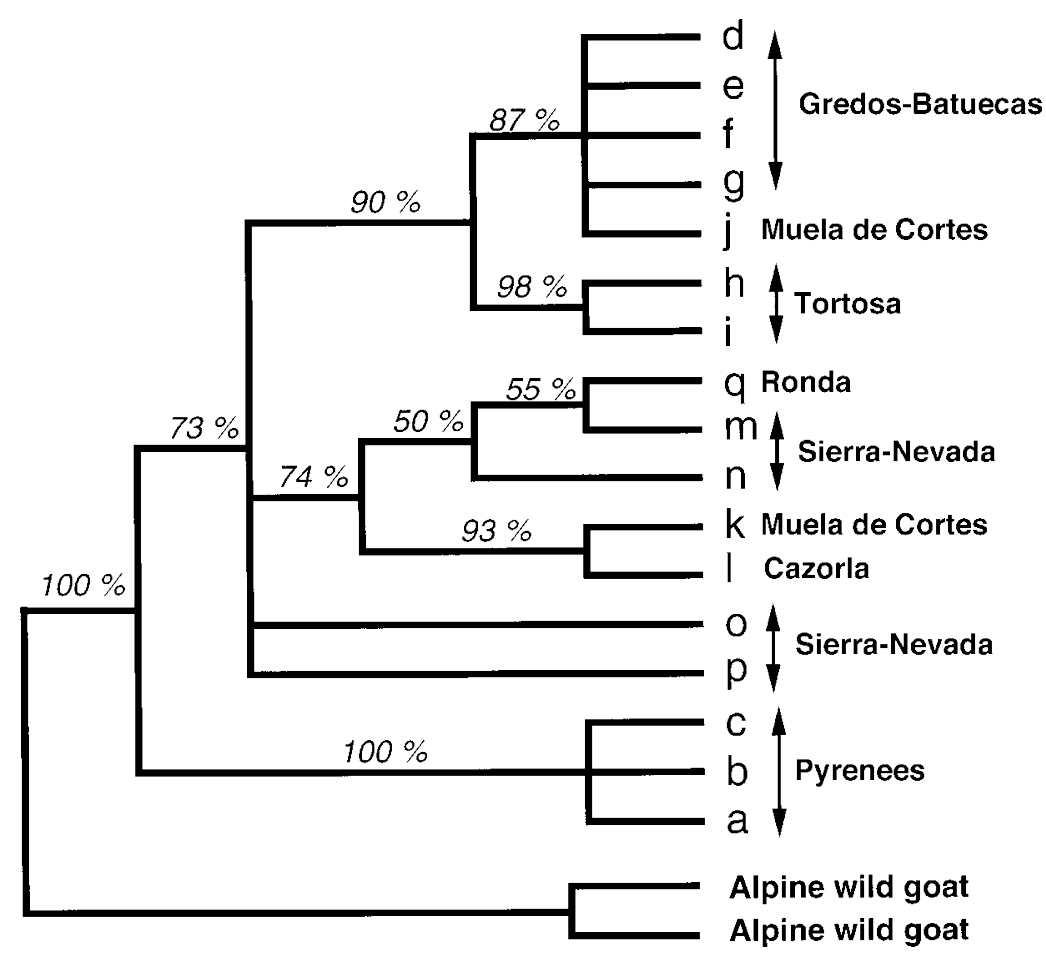

Fig. 3. Parsimony analysis of the $533 \mathrm{bp}$ of the mtDNA control region: consensus tree obtained after 100 bootstrap replicates. The geographic origin of the 17 individuals ( $a$ to $q)$ are shown in Fig. 1. At each internal node, the italic numbers indicate the bootstrap values. Accession numbers: AJ233755 to AJ233770 for zone I, and AJ233739 to AJ233752 for zone II.

diverse population. We therefore suggest that the very low values of within-population polymorphism for the other populations are probably due to the strong bottlenecks they have recently experienced.

Our results describe a clear phylogeographic pattern: the Pyrenean haplotypes $(a, b, c)$ as well as those $(d, e, f, g, h, i, j)$ of the northern populations from the Spanish peninsula are monophyletic (Fig. 3). This could be a recent monophyly resulting from sampling bias due to the recent bottlenecks and small sample sizes analysed. However, each of the Pyrenean and Northern peninsula clades is polymorphic. The different haplotypes present in each of these clades must have pre-existed the recent bottlenecks. If no geographic structuration existed among populations before the bottlenecks, the chance of fixation of a set of related haplotypes in one area and another set in another area would be low. We therefore suggest that our results reveal a structuration that existed before the recent bottlenecks. Isolation between populations from the north-east (Tortosa, Muela de Cortes) and those from the south-east (Cazorla, Sierra Nevada) was not predicted 
because these populations are strongly connected by mountains across which wild goats could disperse. Also unexpected was the relatedness of the north-central (Gredos-Batuecas) and northeastern populations (Tortosa, Muela de Cortes) that are separated by extensive low land. It could be hypothesized that the proximity of haplotypes from northern peninsula populations does not reflect recent gene flow between populations, but rather a shared origin during a presumed expansion following the last glaciation.

Phylogenetic inferences (Manceau et al., 1997) show that the two European Capra spp. are monophyletic when compared to other Capra species. This is consistent with only one wave of immigration of wild goats into Europe. For several European mammals, it has been demonstrated that the deepest split in an intraspecific phylogeny corresponds to the date of immigration (Taberlet et al., 1998). Therefore, we assume that the divergence between Alpine and Spanish haplotypes almost contemporaneous to the divergence between the Pyrenean and other Spanish haplotypes dates the immigration of European wild goats. But, our estimate of the time of immigration (between 0.5 and $2.5 \mathrm{Myr}$ ago) predates largely the estimation given by paleontological records of Capra sp. found so far in the Pyrenees and in Spain (dated around 100 000 years ago; Clot \& Duranthon, 1990; Cregut-Bonnoure, 1992). We thus suppose that gaps could occur in the paleontological records. We also suggest that the Pyrenean population could have been separated from the other Spanish populations just after the immigration or a little later because of geographical discontinuities between the Pyrenean and other Spanish mountains.

\section{Identification of ESUs}

Our mtDNA polymorphism study does not support the recognition of the subspecies victoriae and hispanica but is congruent with the distinctiveness of the Pyrenean population from the other Spanish ones (Fig. 3). As mtDNA is inherited maternally and female wild goat show a higher degree of phylopatry than the males, we would need to test nuclear markers in order to confirm the Pyrenean distinctiveness. Nevertheless, it would be difficult to find informative nuclear markers with only two females left in the Pyrenees. So, we consider the Pyrenean population to be an ESU according to the two independent criteria, the morphological data and mtDNA polymorphism. Its peculiar status should favour the project of hybridization of the remaining females followed by several back-crosses in order to preserve at least part of the original gene pool. Given that there are only two old females left in the Pyrenees and given the technical difficulty of the hybridization conservation strategy, this ESU will probably go extinct very soon. The Pyrenean wild goat could then be considered to be one of the units of the European diversity that has been exterminated during this century. It is unfortunate that the conservation effort had not been initiated earlier 
when the population was larger.

\section{Conservation recommendations}

In order to increase the genetic diversity in some severely bottlenecked populations of Spanish wild goats, we suggest the possibility of mixing populations within the Northern and Southern clades. For the Pyrenean population, since all the other Spanish populations are equally genetically distant from the Pyrenean one, we suggest introducing animals from different populations and/or from the most diverse population. We also recommend carrying out additional studies on nuclear DNA (microsatellites) to identify the level of genetic variability in isolated populations, and to deduce precise management guidelines.

\section{Acknowledgements}

We thank the many collaborators who provided samples, in particular R. Soriguer and P. Fandos who provided samples from Cazorla and Sierra Nevada, J. Losa, S. Valero, J. Miranda, J. Perez, J.-M. Theureau and R. Salas of the national hunting reserves of Spain who helped us collect samples, B. Jada and L. Marquina for the Pyrenean sample and D. Gauthier for the Alpine ones. We thank the director of the I.C.O.N.A who allowed us to collect Spanish samples and M. Aymerich for his help. We also thank C. Dubois-Paganon and L. Gielly for technical assistance, L. Desprès for stimulating discussion and valuable advice during the course of this work,

I. Till-Bottraud, F. Pompanon and G. Luikart for comments on the manuscript. This work was supported by grants from the European Union (LIFE program) and from the Ministère de l'Environnement (D.I.R.E.N. Toulouse).

\section{REFERENCES}

Anderson, S., DeBruijn, M. H. L., Coulson, A. R., Eperon, I. C., Sanger F. \& Young, I. G. (1982). Complete sequence of bovine mitochondrial DNA: conserved features of the mammalian mitochondrial genome. J. Mol. Biol. 156: 683-717.

Avise J. C. \& Ball, R. M. J. (1990). Principles of genealogical concordance in species concepts and biological taxonomy. In Oxford surveys in evolutionary biology: 45-67. Futuyama, D. \& Antonovics, J. (Eds). New York: Oxford University Press.

Boom, R., Sol, C. J. A., Salimans, M. M. M., Jansen, C. L., Wertheim-van Dillen, P. M. E. \& Van Der Noordaa, J. (1990). Rapid and simple method for purification of nucleic acids. $J$. Clin. Microbiol. 28: 495-503. 
Cabrera, A. (1911). The subspecies of the Spanish Ibex. Proc. Zool. Soc. Lond. LXVI: 963-977.

Clot, A. \& Duranthon, F. (1990). Les mammifères fossiles du quaternaire dans les Pyrénées. Toulouse: Museum d'Histoire Naturelle de Toulouse.

Clouet, M. (1979). Note sur la systématique du bouquetin d'Espagne. Bull. Soc. d'Hist. Nat. de Toulouse. 115 (Fasc. 3-4): 269-277.

Corbet, G. B. (1978). The mammals of the Palaearctic Region: a taxonomic review. London: Cornell University Press.

Couturier, M. A. J. (1962). Le bouquetin des Alpes. Grenoble: Arthaud.

Crampe, J. P. (1991) Projet de réintroduction du bouquetin ibérique au versant nord des Pyrénées occidentales. Tarbes: Parc National des Pyrénées.

Crégut-Bonnoure, E. (1992). Les Caprinae (Mammalia, Bovidae) du Pleistocène d'Europe: intérêt biostatigraphique, paléoécologique et archézoologique. Mém. Société Géol. de France 160: 85-93.

Felsenstein, J. (1985). Confidence limits on phylogenies: an approach using the bootstrap. Evolution 39: 783-791.

Felsenstein, J. (1995) PHYLIP: phylogeny inference package. 3.57c. Seattle: Department of Genetics, University of Washington.

Grodinsky, C. \& Stüwe, M. (1987). With lots of help alpine ibex return to their mountains. Smithsonian 18: 68-77.

Hartl, G. B., Burger, H., Willing R. \& Suchentrunk, F. (1990). On the biochemical systematics of the Caprini and the Rupicaprini. Biochem. Syst. Ecol. 18: 175-182.

Hillis, D. M., Mable, B. K. \& Moritz, C. (1996). Applications of molecular systematics: The state of the field and a look to the future. In Molecular systematics: 515-543. Hillis, D. M., Moritz,

C. \& Mable, B. K. (Eds). Sunderland, MA: Sinauer Associates. Hoelzel, A. R. (1992). Molecular genetic analysis of populations.

A practical approach. New York: Oxford University Press.

Irwin, D. M., Kocher, T. D. \& Wilson, A. C. (1991). Evolution of the cytochrome $b$ gene of mammals. J. Mol. Evol. 32: 128-144.

Jukes, T. H. \& Cantor, C. R. (1969). Evolution of protein molecules. In Mammalian protein metabolism: 21-132. Munro, $\mathrm{H}$.

N. (Ed.). New York: Academic Press.

Kumar, S., Tamura, K. \& Nei, M. (1993). MEGA: molecular evolutionary genetics analysis. 1.0. University Park, PA: The Pennsylvania State University. 
Manceau, V., Després, L., Bouvet, J. \& Taberlet, P. (1999). Systematics of the Capra genus inferred from mitochondrial DNA sequence data. Mol. Phyl. Evol. (In revision.)

Moritz, C. (1994). Defining 'evolutionarily significant units' for conservation. Trends Ecol. Evol. 9: 373-375.

Nowak, R. N. (1991). Mammals of the World. (5. edn). Baltimore and London: The Johns Hopkins University Press.

Randi, E., Fusco, G., Lorenzini, R., Toso S. \& Tosi, G. (1991). Allozyme divergence and phylogenetic relationships among Capra, Ovis and Rupicapra (Artyodactyla, Bovidae). Heredity 67: 281-286.

Ruano, G., Fenton W. \& Kidd, K. K. (1989). Biphasic amplification of very dilute DNA samples via 'booster’ PCR. Nucl. Acids Res. 17: 5407.

Ryder, O. A. (1986). Species conservation and systematics: the dilemma of subspecies. Trends Ecol. Evol. 1: 9-10.

Saitou, N. \& Nei, M. (1987). The neighbor-joining method: a new

method for reconstructing phylogenetic trees. Mol. Biol. Evol. 4: 406-425.

Sanger, F., Nicklen, S. \& Coulson, A. R. (1977). DNA sequencing with chain-terminating inhibition. Proc. Natl. Acad. Sci. USA. 74: 5463-5467.

Schaller, G. B. (1977). Mountain monarchs: wild sheep and goats of the Himalaya. Chicago: The university of Chicago Press.

Shackleton, D. M. (1997). Wild sheep and goats and their relatives. Status survey and conservation action plan for Caprinae. Gland and Cambridge: IUCN.

Southern, S. O., Southern, P. J. \& Dizon, A. E. (1988). Molecular characterization of a cloned dolphin mitochondrial genome. J. Mol. Evol. 28: 32-42.

Swofford, D. L. (1993) PAUP: Phylogenetic analysis using parsimony. 3.1.1. Champaign, IL: Illinois Natural History Survey.

Taberlet, P. \& Fumagalli, L. (1996). Owl pellets as a source of DNA for genetic studies of small mammals. Mol. Ecol. 5: 301-305.

Taberlet, P., Fumagalli, L., Wust-Saucy, A. G. \& Cosson, J. F. (1998). Comparative phylogeography and postglacial colonization routes in Europe. Mol. Ecol. 7: 453-464.

Upholt, W. B. \& Dawid, I. B. (1977). Mapping of mitochondrial DNA of individual sheep and goats : rapid evolution in the Dloop region. Cell 11: 571-583.

Waples, R. S. (1991). Definition of 'species' under the Endangered Species Act: application to Pacific salmon. NOAA Technical Memorandum NMFS F/NWC-194. Seattle: National Marine Fisheries Service. 